\title{
Landscape conservation in the research and development of the Krakow School of landscape architecture from 1970s to 2017 - from Jurassic landscape parks to cultural parks in Krakow
}

\author{
Urszula Forczek-Brataniec, Zbigniew Myczkowski, Cracow University of Technology
}

\begin{abstract}
It has been almost 70 years since, when "atlantis" of the Cracow's School of Landscape Architecture professor Zygmunt Novák put forward the first idea of creating a Jurassic Landscape Park as an area where the landscape is protected in order to ensure a rest for people in the beautiful nature and culture of the surrounding great cities. Since then, his pupils and successors have created a school based on a characteristic methodology, approach to the landscape. The idea was continued in conjunction with the changing technologies and possibilities. As a result, a set of good practices was created that characterized Krakow's school of landscape architecture and emphasized its pragmatic nature.
\end{abstract}

Keywords: Krakow's school of landscape architecture, landscape parks, cultural parks, cultural landscape

It is already close to 1970s from the time when the "atlantes" of "Krakow School of landscape architecture" Professor Zygmunt Novák [6] put first the idea of creation of a Jurassic landscape parks, as an area in which protects a landscape to provide leisure in beautiful nature and culture in an environment of big cities. Alluded to the world sources of landscape architecture, the "father" of F. L. Olmsted Sr., whether the definition of Ch. Eliot, who said, that the priority of the function of landscape architecture, which is "to create and protect beauty."

Landscape, according to statements by Zygmunt Novák [6] is a synthesis of all the developments in the human environment; natural and cultural heritage. This includes "the face of the Earth" [10] - "new heritage a new civilization", which we will leave to the next generations.

Landscape is the physiognomy - the expression of environment, the reflection of all phenomena occurring on the surface of the Earth [1]. The environment-both natural cultural-is about the identity of the place, and its external expression is landscape. You cannot, or hide, or to see the landscape, although it can be for its beauty, or at least, more or less sensitive. It always press on human beings, even if only in the realm of the subconscious mind. It is difficult to us to remain indifferent to the beauty of the mountains, the village or the historic town. After all, just knowing that somewhere in the country is beautiful - we take a trip there and the de facto is in things hits to its landscape, for example, the

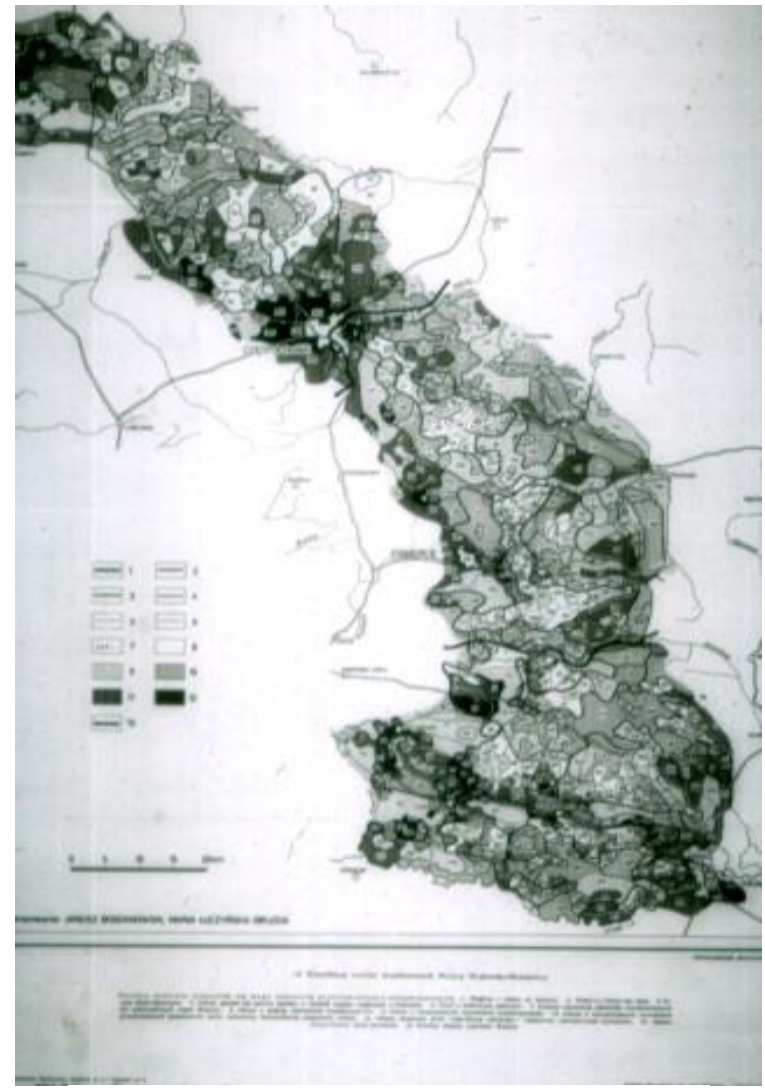

Fig. 1. Pioneering vision plan Jurassic landscape parks stretching $150 \mathrm{~km}$ north of Kraków.

Created by Z. Novák, M. Łuczyńska-Bruzda and J. Bogdanowski, 1970. 


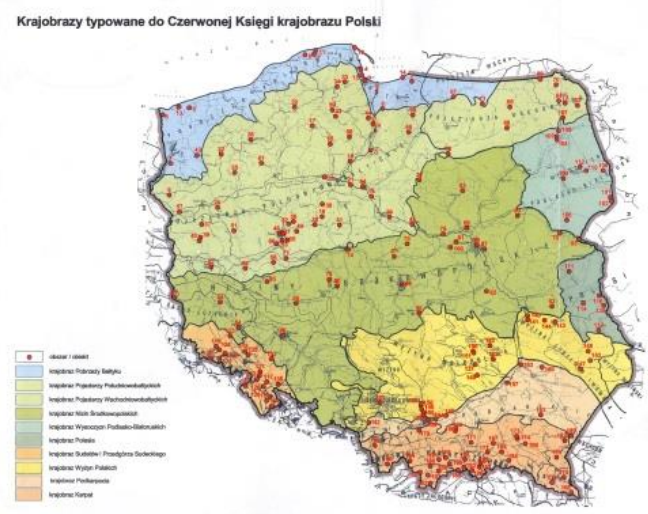

Fig. 2. The arrangement of the predefined typed landscapes to be included in the Red Book of Landscapes

Polish. M. Baranowska-Janota, R. Marcinek, Z. Myczkowski, Kraków, 2004.

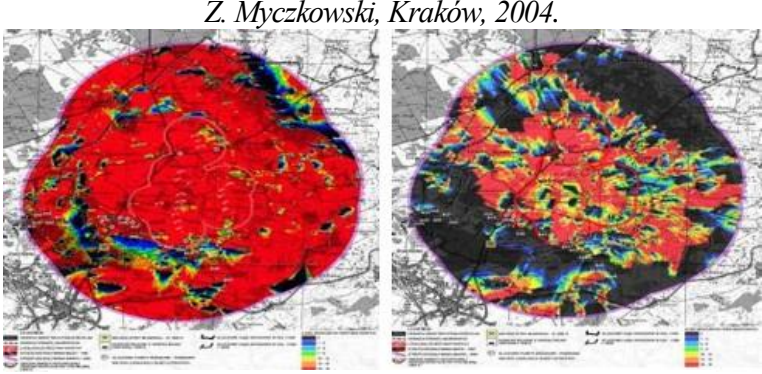

Fig. 3. Comparison of exposure potential and actual team proposed wind towers in the municipality of Wieczfnia. U. Forczek-Brataniec, P. Nosalska, 2008.

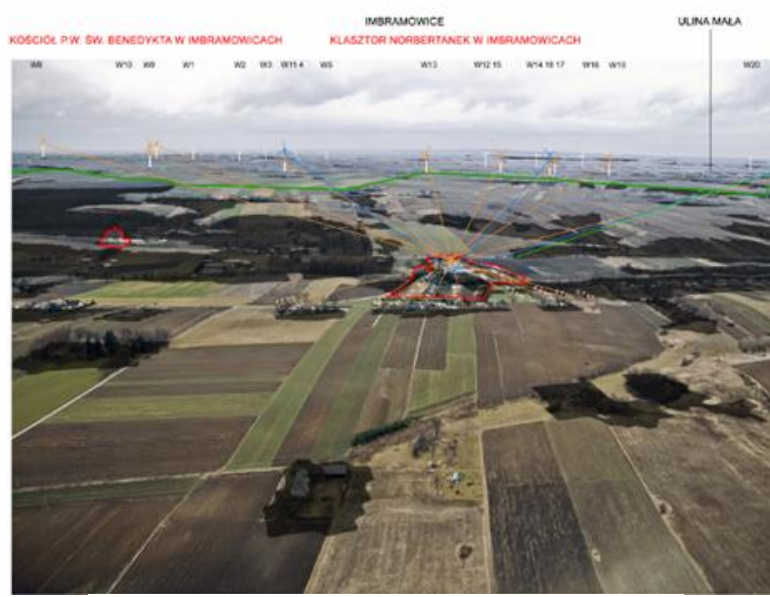

Fig. 4. An example of visualization of the guidelines for the proposed wind towers

[U. Forczek-Brataniec, P. Nosalska 2008].

Baltic coast, the Tatra mountains or the historic town of Torun, Krakow or Krakow-Częstochowa Jurrasic Highlands and harmoniously formed extensive agricultural countryside of Opole region or lower Silesia. You should also realize that the natural monument or historic building, which so we value is the only element of the landscape [8]. In our environment we are dealing with the natural landscape, which is the work of nature, and of the cultural landscape, which is be creation thought and human hands but most often, with mix of sorts of their good or bad interfere. Aptly had recognized it Gutherson [2], writing that landscape is the expression of the human economy. Therefore, the good economy is the basis for harmonious landscape, evil is devastated, and vice versa: devastation of the landscape is an expression of bad economy. This statement is completed by Professor Kostrowicki [4], saying that: "you can false the statistics, reports, documentation - in case of landscape it is not possible - he always tells the truth about us and our economy and management."

One of the primary tasks facing the modern hosting landscape - Government authorities and local self-government seems to be taking care of his harmonious, Marks half a century since the position of the foundations for the formulation of one the most original and the most durable methods of registration, evaluation and the formulation of guidelines for landscaping. This is the method of architectural and landscape architectural and interior design-unitslandscapers (JARK and WAK). Designed and developed in a team of landscape architecture at the Faculty of architecture, under the direction of Prof. Janusz Bogdanowski, Prof. Maria ŁuczyńskaBruzda - was before 40 years implemented and checked various tasks and scales the spatial Method of 1970s . was also an element of didactics-first at the level of the theses, and over the 1990s, also on the design landscape architecture range exercises foreign exchange at the Technical University of Cracow, AGH University and at the University of Agricultural in Krakow.

In the 1970s the professors Z. Novák, M. Łuczyńska-Bruzda and J. Bogdanowski developed the first plans - functional Jurassic landscape parks at the Faculty of Architecture of Technical University of Cracow. In the 1990s J. Bogdanowski, M. Łuczyńska-Bruzda and Z. Myczkowski are coauthors of the Government statement for security plans of national parks, and then are the main authors of the documentation for the Bieszczady National Park, the Tatra NP, Pieniny NP (with the U. ForczekBrataniec). Breakthrough of the 20th and 21st centuries resulted in, inter alia, A National Programme of Landscape Protection Historical (maintained by J. Bogdanowskiego) and monograph cultural landscape of Małopolska region [9].

Almost parallel to the ratification by Poland in the year 2005 the European Landscape Convention from the year 2000 - 2008 year in the National Centre of Research and Documentation Monuments was launched for the implementation by the year 2015 the program protection landscape Polish culture. It is in part a continuation of the national programme "protection and maintenance of the historic cultural landscape" carried out in the years 1996-2000 by the professor Janusz Bogdanowski, which recognized approx. $88.5 \%$ of the country [5]. At the same time, are at the beginning of the 21 st century, records an entry in the list of UNESCO and their projects 
(m.in. Gothic wooden churches of lesser Poland (J. Bogdanowski, M. Kornecki, Z. Myczkowski. Marcinek, A. Siwek, 2003).

In the year 2005 in the pilot project "Red Book of the Polish Countryside"/M. Baranowska-Janota, Z. Myczkowski, R. Marcinek/at the State Council for the Conservation of Nature by the Minister for the Environment were the most valuable areas 198 landscape on the background of the more than 400 at issue. Can be assessed, at least $50 \%$ of a high value and distinctive cultural landscape in Poland is at risk of intense transformation.

Consists of no first of all: very low security areas in local land-use plans that do not cover even $80 \%$ of the country. Consequently, dispersion and freedom of action on the basis of the decisions of the land.

At the turn of the first and second decades of the 21 st century, the authors of this speech did numerous landscaped expertise in Visual impact of wind farms and other infrastructure facilities in the landscape. The distinctive factors in these analyses is the exposure potential and actual, active and passive [3].

For the detailed examination of the impact of observation under the strongest impact of the investment shall be made digital terrain models with a range of $5 \mathrm{~km}$, which allows you to assess the potential and actual observation range objects and check for interference with the view of the most valuable areas. Very interesting effect was obtained by comparing the map visibility towers made for exposure potential is based on the terrain of the real exposure-taking into account the elements of the cover in the form of wooded areas and buildings. A summary of these maps allows you to see the clear differences in the degree of interference with the observation made in the size of the red and black stains.

Studies have shown that exposure to wind towers with a height of 140 meters nacelles axis objects beyond a certain distance become essential elements of the cover in the form of wooded areas and buildings. Even so, a significant difference in altitude does not diminish the role mask of tree stands. Work on the model made it possible to convert the cartographic data to numeric data. The visualizations are the level of wind towers to be interfered with in the landscape.

You can confirm that a more appropriate place for spatial structures in the form of team's wind towers are sites with diverse topography. On the flat areas of the windmills are seen from the large areas, which presents a lot less aggressively than those located above, for example on the highland. The surrounding extensive landscape provides a context, soothing the actual dimensions of the objects. Infrastructure elements visible within $35 \mathrm{~km}$ take over the main role of display. Become the so-called the visual element of the main roads, hiking trails, bike paths and any surrounding strings. Windmills are taking in this context, the role of landscape character area.

In June 1993 year came a message from UNESCO, to serve a known "World Heritage list" also cultural landscapes on the CSCE Conference in Krakow, 1991 year, at the request of the Polish typed was first postulate about the need for the inclusion in the scope of concern for European heritage.

When today we talk in Europe about the homeland regions, closer to the familiarly known as vernacular forms as in the more generally as local and topical, what better this example and write. Today also, when floods us cities beautiful-the sophistication of bizarre shapes often architecture, passive and ugliness is replaced by aggressive, brutal forms, it's time to realize the relevance of the idea of "fighting a real culture against quasi culture". The protection of the cultural landscape in the form of 22 existing cultural parks provides for the establishment of a further 250 in provincial programs and strategies for the preservation of historical monuments including more than 150 initiatives.

In the following years are also exemplary, awardwinning Cultural Parks protection plans (Downtown in Krakow, K. Wielgus, U. Forczek-Brataniec, Z. Myczkowski and others, 2013), Nowa Huta (2016) and currently Work in Zakopane (2017). Cultural Park protection plan "Downtown" in Krakow was established on the basis of the best-known development of historical, archaeological, architectural, planning, nature and landscape, which was made for the same area [10].

Cultural Park protection plan greatly expands the controlled statutory character and contents of the plan, therefore, the study uses a different method of allocation, valuation and define guidelines, than starting materials plan the local. In the first place, in the development of a security plan, the division of the old town was based on criteria taking into account the record of past and ongoing process here. The division has allowed to identify areas with consistent characteristics, however, the various components of the urban landscape. In place of the mechanical breakdown on the streets, blocks and green areasareas was obtained consistent in terms of origin, use, form, size of objects - and hence, with similar conditions and problems not only conservatoryprotective or the scenic, but also for example. social, or associated with the intensity of tourism.

The complexes with similar characteristics are combined in larger areas, named landscape models of the old town. About their identity and distinctiveness are both differences in the structure of the building, as well as various scale and scenic aspects of the meanings. Exposé means the most important openings and viewing links is another feature specific 


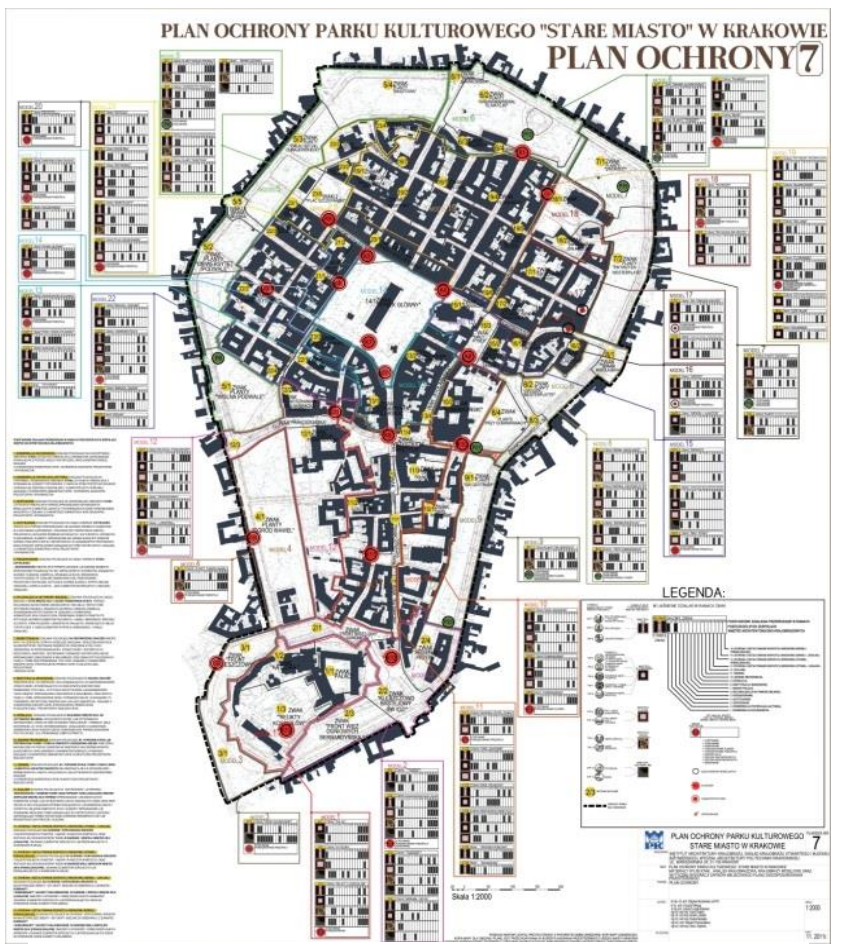

Fig. 5. Park protection plan Cultural Park of Downtown in Krakow

Created by Z. Myczkowski, K. Wielgus, U. Forczek-Brataniec, K. Latusek, K. Chajdys, P. Nosalska,

W. Rymsza-Mazur, O. Zapolska, 2011.

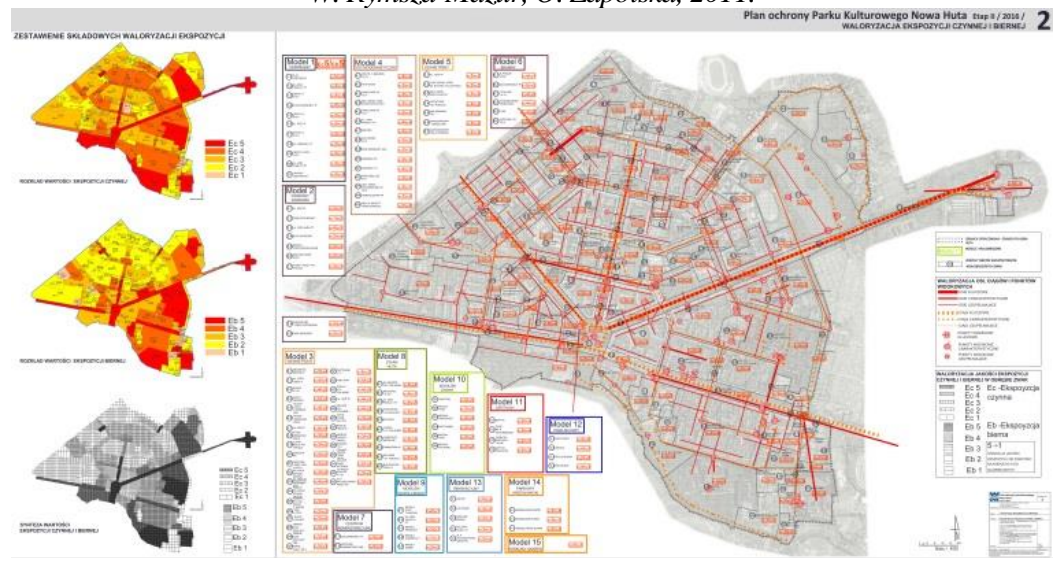

Fig. 6. Protection plan of the Cultural Park of Nowa Huta in Kraków. Created by Z. Myczkowski, K. Wielgus, U. Forczek-Brataniec, K. Latusek, K. Chajdys, R. Marcinek, A. Siwek, P. Nosalska, W. Rymsza-Mazur, 2016.
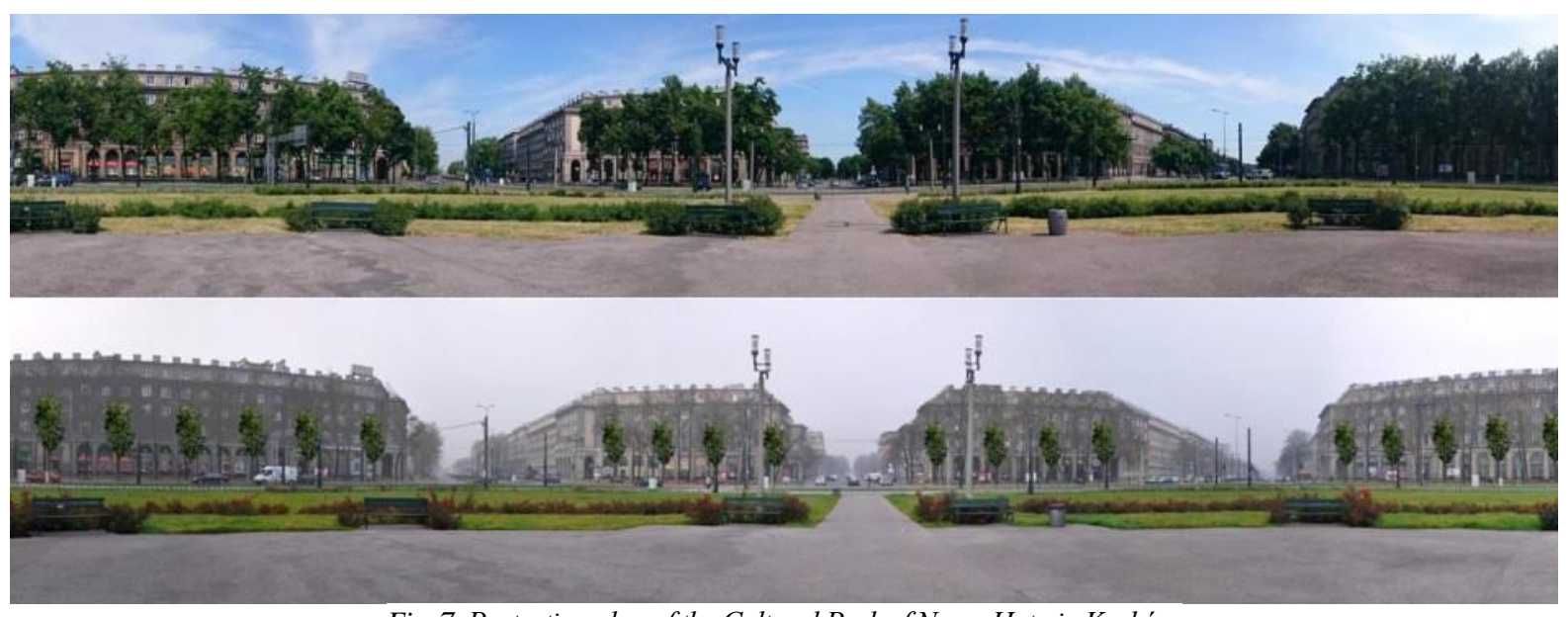

Fig. 7. Protection plan of the Cultural Park of Nowa Huta in Kraków, the concept tree stand reconstruction in order to uneveiling the frontage of the square. 


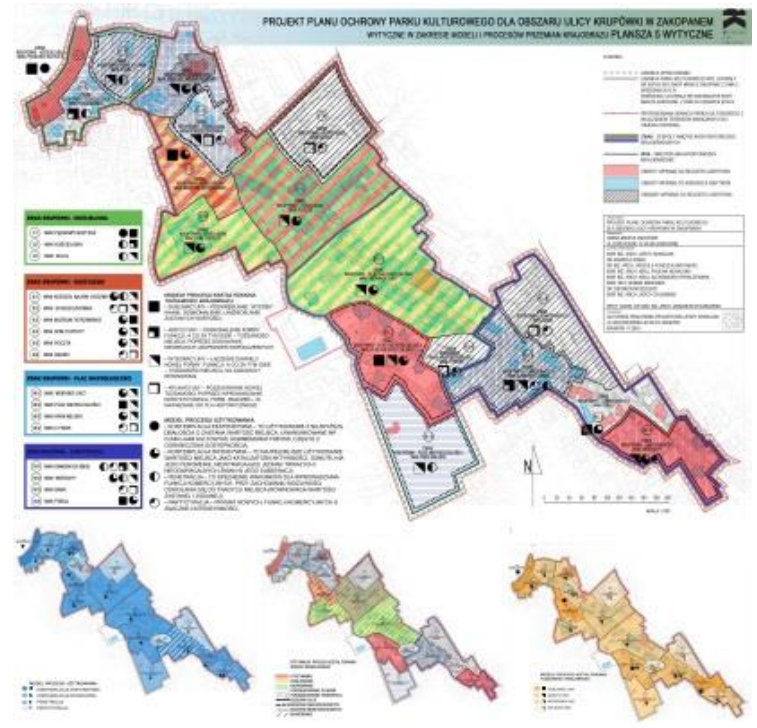

Fig. 8. A Cultural Park in Zakopane Krupówki. The Protection Plan. Guidelines by Z. Myczkowski. J. Wowczak, U. Forczek-Bratanec, R. Marcinek, A. Siwek, P. Nosalska and A. Rykaczewska, 2017.

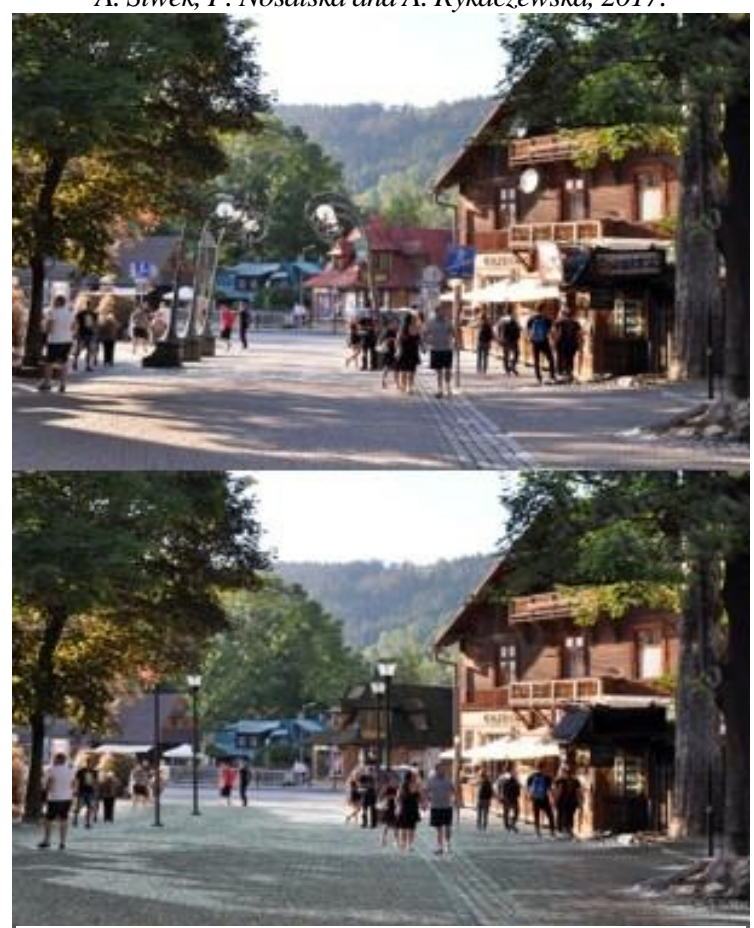

Fig. 9. A cultural Park in Zakopane Krupówki Protection Plan Visualizations of the current status and proposed after regeneration. By U. Forczek-Bratanec, P. Nosalska 2017.

Cultural Park protection plan, to differentiate it from other documents, for example - the local spatial plan.

Based on the valorization, directional guidance landscaping for individual teams decor architectural and landscape, by specifying for each type (such as courtyards, courtyards, streets, gardens), occurring in the Assembly. Guidelines for individual teams' decor and landscape models compared then with the detailed provisions of the local plan and assigned individual, as defined by the plan of action is to specific, individual portions of the city. It was formed in this way a kind of "dictionary" activities, reaching more precisely in the problems and needs of the city, divided into easier in the diagnosis, management and monitoring of the operational areas.

Cultural Park protection plan captures great detail trends of use of, data part of the transformation, the scale of risks and potential investment pressures but the directions of the active use of the best, and often untapped aspects of attractiveness. This tool can develop and updated at the level of the management plan for the Park. Ways to manage are particularly important for the management of protected areas in the highest values, covered by the entry in the list of monuments of history and heritage.

The Krakow cartridge research workshop and methodical landscape architecture is leading both in terms of documentation, as well as deployments of these pioneering implementation of regional, national and international scale.

Observing what is happening in the field of the protection of the landscape in the world, in Europe and in Poland - it can be stated that, as it were, in front of the landscape diversity "comes out" the plurality and diversity of forms of protection. Nature protection, which, as it were, "ahead" in Poland to protect historical sites identified in the last version of the Act on Nature Protection act of 16 April 2004 year - the scenic landscape, as the value of the ecological, aesthetic or cultural area and the related sculpture the site, from and nature shaped by the forces of nature or human activity. For their protection in article 16 confirmed laid down from the beginning of the eighties the landscape protection area is a landscape park, which according to the statutory definition includes a protected area due to natural values, historical and the cultural and scenic landscape in order to preserve, promote these values in terms of sustainable development. Currently we have in Poland more than 120 of landscape parks, which account for more than 7 percent of the country.

In turn, the Act on the protection of monuments and the care of monuments from 23 July 2003 defines the cultural landscape as historically shaped as a result of human activity, including the creations of civilization and natural elements in many environments, there have been a great interest in creating this type of tool, used both the renewal of the values of cultural heritage and their use for economic stimulation, especially for the development of tourism. To meet the increasing social demand of.

Institute of Landscape Architecture Cracow University of Technology, undertook the development "principles of creating cultural Park, its management and draw up a plan for its protection". It was indicated in the proposals for action do not constitute a provision specifying the need to develop a set of specific documents or take the necessary steps required by law. 
At this stage, putting the first steps by both the local and regional authorities, as well as restorers and cooperating in creating cultural parks professionals and social groups, difficult or even impossible to predict what problems retained, the social, economic and organizational need to face. In the "Rules" indicated was the scenario of issues and activities developed on the principle of "step by step", which probably will further improve in the next few years, as you gain experience, which will bring the process of creating cultural parks Poland.

\section{References}

1. Bogdanowski J., Myczkowski Z. From conservation of monumental buildings to protection of monumental cultural landscape. In: Duties towards the heritage and laws of the market, ICOMOS. Cracow: International Cultural Centre Cracow, 1996.

2. Buchwald K., Engelhardt W. Ksztaltowanie krajobrazu a ochrona przyrody. Warszawa: PWR i L, 1975.

3. Forczek-Brataniec U. Przestrzeń widziana. Analiza widokowa w planowaniu i projektowaniu krajobrazu. Visible space. A visual analysis in the landscape planning and designing. Kraków: Politechnika Krakowska, 2018.

4. Kostrowicki J., Środowisko przyrodnicze, a stan zagospodarowania, In: Uwarunkowania środowiska w planowaniu przestrzennym, konferencja PZiTR, Kraków 1970.

5. Myczkowski Z. Krajobraz wyrazem tożsamości w wybranych obszarach chronionych w Polsce. Kraków: Politechnika Krakowska, 2003. 228 p.

6. Novak Z. Planowanie regionalne i udział w nim architekta. Kraków: Politechnika Krakowska, (1950; reprint) 1997.

7. Luczyńska-Bruzda M., Myczkowski Z. Subregionalizacja cech budownictwa jako przyczynek do kontynuacji tradycji we współczesnej architekturze regionalnej (na przykładzie Jurajskich Parków Krajobrazowych). Kraków: Teka KUiA, t. XXVI, 1993/94.

8. Myczkowski Z., Uwarunkowania kulturowe zagospodarownia przestrzennego województwa krakowskiego In: Teki Krakowskie III ROSiOŚK, Kraków, 1996.

9. Pawlikowski J. G. O lice ziemi. Wybór pism Jana Gwalberta Pawlikowskiego. Warszawa: Wydaw. Państwowej Rady Ochrony Przyrody, 1938.

10. Myczkowski Z., Forczek-Brataniec U., Wielgus K. Plan ochrony Parku Kulturowego Stare Miasto w Krakowie w kontekście ochrony i planowania krajobrazu miasta In: XV Forum Architektury Krajobrazu Planowanie Krajobrazu 1617 listopada Lublin-Kazimierz, Dolny, 2012, p. 32-34.

INFORMATION ABOUT THE AUTHORS:

Zbigniew Myczkowski - Associate Professor, Professor at the Landscape Architecture Institute, Technical University in Cracow Poland. 31-155 Kraków, ul. Warszawska 24, e-mail: zbyszekm@pk.edu.pl

Urszula Forczek-Brataniec - PhD of Technical Sciences in the field of Architecture, Associate Professor at the Landscape Architecture Institute of Cracow University of Technology of Poland, ul. Warszawska 24, 31-155 Kraków, Poland, e-mail: uforczek-brataniec@pk.edu.pl

Kopsavilkums. Ir pagājuši gandrīz septiņdesmit gadi kopš Krakovas Ainavu Arhitektūras skolas leǵenda un profesors Zigmunds Novāks (Zygmunt Novák) radīja ideju par Juras Laikmeta Ainavu parka izveidi, paredzot to kā vidi, kurā ainava ir pasargāta un baudot kultūru, nodrošinot cilvēkiem mierīgu atpūtu dabā. Kopš tā laika viņa mācekḷi un pēcteči ir izveidojuši skolu, kas ir balstīta uz ainavām raksturīgām metodologijām. Ideja ir radusi turpinājumu, izmantojot mūsdienu attīstītās tehnoloǵijas un iespējas. Rezultātā ir iegūti veiksmīgas prakses piemēri, kas raksturo Krakovas Ainavu Arhitektūras skolu un izceḷ tās pragmatisko dabu. 